ISSN: 1907-9931 (print), 2476-9991 (online)

\title{
PERFORMA UDANG VANAME Litopenaeus vannamei (Boone, 1931) YANG DIPELIHARA PADA SISTEM BIOFLOC DENGAN SUMBER KARBON BERBEDA PERFORMANCE OF VANAME SHRIMP Litopenaeus vannamei (Boone, 1931) MAINTAINED IN BIOFLOC SYSTEMS WITH DIFFERENT CARBON SOURCES
}

\author{
Supono $^{1^{\star}}$, Rehulina Tresia Pinem ${ }^{1}$, Esti Harpeni ${ }^{2}$ \\ ${ }^{1}$ Program Studi Budidaya Perairan, Jurusan Perikanan dan Kelautan Universitas Lampung \\ ${ }^{2}$ Program Studi Kelautan, Jurusan Perikanan dan Kelautan Universitas Lampung \\ *Corresponden author email: Supono_unila@yahoo.com
}

Submitted: 10 December 2020 / Revised: 30 August 2021 / Accepted: 30 August 2021

http://doi.org/10.21107/jk.v14i2.9191

\begin{abstract}
The intensive cultivation of Litopenaeus vannamei with biofloc systems is one of the most efficient way to reduce shrimp cost production, because the biofloc can be used as feed subtitution for $L$. vannamei cultured. The application of the biofloc system in commercial ponds is still experiencing many obstacles so that it is not optimal in supporting the success of cultivation. One of the factors that determine the success of shrimp farming with a biofloc system is the determination of the right organic carbon source. The objective of this research was to know the effect of addition of C-carbohydrate (wheat, tapioca, and mollases) on shrimp growth, survival rate, biomass, efficency of feed and feed conversion ratio of white shrimp $L$. vannamei. The design of the research was using a completely randomized design, consisted of three experimental treatments with four replications. The result of this research showed that the biofloc systems with addition of C-carbohydrate on growth performance of the shrimps were not significantly different $(P>0.05)$ among those treatments. The biofloc technology with addition of $C$-carbohydrate using treatment $B$ (wheat) showed higher survival rate $(S R)$, biomass, feed conversion ratio (FCR), and feed efficiency were significantly different $(P<0.05)$ than the $C$-carbohydrate from treatment $C$ (tapioca) and $D$ (mollases). The bioflocs system with addition of C-carbohydrate from treatment $B$ (wheat) had SR (75.4 $\pm 7.2 \%)$, biomass $(256,8 \pm 23,6 \mathrm{~g})$,

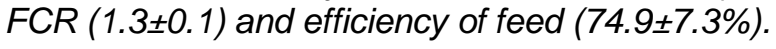

Keyword: biofloc, wheat, tapioca, mollase,

\section{ABSTRAK}

Budidaya udang vaname (Litopenaeus vannamei) secara intensif menggunakan sistem biofloc merupakan salah satu upaya efisiensi biaya produksi, karena biofloc dapat dimanfaatkan sebagai alternatif pakan bagi udang vaname yang dibudidayakan. Aplikasi sistem biofloc di tambak komersial masih mengalami banyak kendala sehingga tidak optimal dalam mendukung keberhasilan budidaya. Salah satu faktor yang menentukan keberhasian budidaya udang dengan system biofloc adalah penentuan sumber karbon organic yang tepat. Tujuan penelitian ini adalah untuk mempelajari pengaruh penggunaan sumber karbon organik yang berbeda dalam sistem biofloc terhadap pertumbuhan, tingkat kelangsungan hidup, biomassa, efisiensi pemanfaatan pakan, dan konversi pakan udang vaname. Rancangan penelitian yang digunakan adalah rancangan acak lengkap (RAL) terdiri dari 3 perlakuan dengan 4 ulangan. Ketiga perlakukan sumber karbon organik tersebut adalah gandum, tapioka, dan molase. Pemeliharaan udang vaname dilakukan selama 35 hari. Hasil penelitian menunjukan bahwa perlakuan sistem biofloc dengan penambahan sumber karbon organik yang berbeda tidak berpengaruh nyata terhadap pertumbuhan mutlak dan spesifik udang vaname $(P>0.05)$. Penggunaan sumber karbon organik yang berbeda berpengaruh nyata terhadap tingkat kelangsungan hidup, biomasa, konversi pakan, maupun efisiensi pakan udang vaname. Sumber karbon gandum menghasilkan tingkat kelangsungan hidup, biomassa, konversi pakan, dan efesiensi pemanfaatan pakan yang lebih baik dibandingkan dengan sumber karbon tapioka dan molase. Penggunaan sumber karbon gandum dalam sistem biofloc menghasilkan nilai tingkat kelangsungan 
Kata kunci: biofloc, gandum, molase, tapioka

\section{PENDAHULUAN}

Sistem Biofloc telah banyak diaplikasikan dalam budidaya perairan terutama ikan nila (Avnimelech, 2015; Ogello et al., 2014) dan udang vaname (Hien, 2012; Haslun et al., 2012; Supono et al., 2014). Teknologi biofloc memiliki beberapa kelebihan antara lain: meningkatkan kualitas air (Crab et al., 2012), meningkatkan pertumbuhan dan efisiensi pakan, serta memperbaiki imunitas udang dan ikan (de Schryver et al., 2008). Bakteri penyusun biofloc mampu menghasilkan polyhydroxybutyrate (de Schryver et al., 2010; Supono et al., 2013,). Polyhydroxybutyrate (PHB) dapat memacu pertumbuhan (Bossier, 2010), menekan vibrio pada saluran pencernaan (Boon et al., 2010; Crab et al., 2010), dan mampu meningkatkan imunitas ikan nila (Suguna et al., 2013).

Prinsip dasar aplikasi sistem biofloc adalah mengatur keseimbangan antara karbon organik dan nitrogen anorganik dalam kolam (Crab et al., 2012). Pertumbuhan bakteri heterotrof dipacu dengan meningkatkan rasio karbon (C) terhadap nitrogen (N) (Avnimelech, 2015). Rasio C:N media lebih dari 12,5 akan menyebabkan dominasi bakteri heterotrof sebagai penyusun utama biofloc (Hargreaves, 2013). Sumber karbon organik digunakan oleh bakteri heterotrof untuk membentuk biomasa bakteri dengan memanfaatkan $\mathrm{N}$ anorganik dalam bentuk $\mathrm{NH}_{4}{ }^{+}$ maupun $\mathrm{NO}_{3}{ }^{-}$(Ebeling et al., 2006).

Dalam kolam budidaya, karbon organik maupun nitrogen anorganik sumber utamanya dari pakan yang diberikan. Amnoniak berasal dari sisa pakan, feses, maupun sisa metabolisme yang dikeluarkan melalui insang (Crab et al., 2007). Rata-rata karbon yang terbuang ke lingkungan kolam sekitar $80 \%$, sementara nitrogen sekitar $75 \%$ (Piedrahita, 2003). Menurut Sahu et al., (2012), nitrogen yang diretensi menjadi daging udang sebesar $30 \%$ dan karbon sebesar $18 \%$.

Rasio C:N media budidaya tergantung dari jenis pakan yang digunakan, terutama kandungan proteinnya. Semakin tinggi kandungan protein pakan, rasio C:N semakin kecil (Avnimelech, 2009). Pakan udang vaname yang biasa digunakan mengandung protein $30 \%$ memiliki rasio C:N sebesar 10,4. Untuk meningkatkan rasio $\mathrm{C}: \mathrm{N}$ perlu dilakukan penambahan sumber karbon. Sumber karbon organik yang aman digunakan dalam budidaya perairan berasal dari karbohidrat seperti tepung terigu, gula, tapioka, maupun molase (Avnimelech, 2015). Molase merupakan produk samping dari pabrik pembuatan gula. Sumber karbon tersebut memiliki beberapa kelebihan seperti: mudah diperoleh, harganya murah, dan mudah diuraikan. Beberapa sumber karon memiliki tingkat penguraian yang berbeda di dalam air, seperti gula yang memiliki haf-life 0,6 hari (Reddy et al., 1986). Menurut De Schryver et al. (2008), pemilihan sumber karbon organik memengaruhi pertumbuhan floc. Tujuan penelitian ini adalah mempelajari efektivitas penggunaan sumber karbon yang berbeda dalam sistem biofloc untuk meningkatkan pertumbuhan, efisiensi pakan, dan tingkat kelulushidupan dang vaname (L. vannamel).

\section{Waktu dan Tempat}

\section{MATERI DAN METODE}

Penelitian ini dilaksanakan pada Desember 2019-Januari 2020 di Laboratorium Lapangan Terpadu dan Laboratorium Perikanan, Fakultas Pertanian Universitas Lampung.

\section{Bahan Penelitian}

Bahan yang digunakan pada penelitian yaitu air laut, bakteri Bacillus coagulans, udang vaname PL 10, pakan komersil (kadar protein $30 \%$ ), $\mathrm{NH}_{3}$ dan $\mathrm{NO}_{2}$ test kit, tepung tapioka, gandum, dan molase, $\mathrm{BaCl}_{2} 1 \%, \mathrm{H}_{2} \mathrm{SO}_{4} 1 \%$, media trypticase soy broth (TSB), dan media sea water complete (SWC) yang meliputi; media bacteriological agar (BA), bacto pepton (BP), Yeast extract powder, glycerol, akuades dan air laut.

\section{Rancangan penelitian}

Rancangan penelitian yang digunakan yakni rancangan acak lengkap (RAL) yang terdiri dari 3 perlakuan dengan 4 ulangan. Perlakuan tersebut sebagai berikut:

Perlakuan A: Biofloc dengan sumber karbon organik tepung gandum

Perlakuan B: Biofloc dengan sumber karbon organik tepung tapioka

Perlakuan C: Biofloc dengan sumber karbon organik molase.

\section{Prosedur penelitian \\ Persiapan wadah budidaya}

Penelitian dilakukan pada ruangan semi outdoor menggunakan akuarium berukuran $60 \mathrm{~cm} \times 40 \mathrm{~cm} \times 35 \mathrm{~cm}$ sebanyak 16 unit. Sterilisasi 
akuarium menggunakan kaporit dengan dosis 25 $\mathrm{mg} / \mathrm{L}$. Masing-masing akuarium diisi air hingga volume $70 \mathrm{~L}$ dengan salinitas 28 ppt. Masingmasing akuarium dilengkapi dengan aerator sebagai suplai oksigen.

\section{Kultur biofloc}

Pakan udang ditimbang sebanyak 35 gram dan dimasukkan dalam tiap akuarium dengan volume air 70 liter. Sumber karbon eksternal (gandum, tapioka, dan molase) ditambahkan pada masingmasing wadah dengan rasio $\mathrm{C} / \mathrm{N} 15$ dan dilakukan aerasi sebagai suplai oksigen agar bahan-bahan yang dimasukkan tidak mengendap. Sebanyak $60 \mathrm{ml} \times 10^{6} \mathrm{CFU} / \mathrm{ml} B$. coagulans ditambahkan ke dalam setiap akuarium sebagai sumber bakteri heterotrof.

Bakteri B. coagulans dibiakan menggunakan media SWC (Sea Water Complate) $75 \%$ air laut pada agar miring untuk mendapatkan biakan yang lebih muda. Selanjutnya bakteri diambil menggunakan jarum ose sebanyak 1-2 kali ulangan ke dalam wadah erlenmayer yang berisi media TSA (Trypticase soy agar), kemudian dishaker selama 24 jam untuk meningkatkan kepadatan bakteri yang akan ditebar pada wadah pemeliharaan..

\section{Pemeliharan ikan uji}

Udang vaname PL10 ditebar dengan kepadatan 70 ekor/akuarium (1 ekor/L) dipelihara selama 35 hari. Aklimatisasi dilakukan pada saat penebaran udang ke dalam akuarium. Frekuensi pemberian pakan diberikan 3 kali sehari $(06.00,12.00$, dan 19.00 WIB) menggunakan metode blind feeding berdasarkan asumsi berat udang dan feeding rate (Supono, 2017). Sampling bobot udang vaname dilakukan sebanyak $30 \%$ dari populasi untuk mengetahui bobot rata-rata udang vaname pada awal pemeliharaan. Pakan yang digunakan berupa pakan komersil dengan kandungan protein $32 \%$. Penambahan sumber karbon (molase, tepung gandum, dan tepung tapioka) dilakukan setiap hari pada pukul 08.00 WIB dengan rasio $\mathrm{C} / \mathrm{N}$ media 15 pada masing-masing perlakuan. Penambahan sumber karbon eksternal (molase, tepung gandum, dan tepung tapioka) dilarutkan menggunakan air hingga homogen selanjutnya dilakukan penebaran sumber karbon pada masing-masing perlakuan.

\section{Parameter Pengamatan Kandungan Karbon dan Nitrogen}

Sumber karbon yang digunakan pada penelitian berupa gandum, tapioka, dan molase. Uji kandungan karbon dan nitrogen dilakukan di
Laboratorium Analisis Politeknik Negeri

Lampung.

\section{Pertumbuhan Berat Mutlak}

Pertumbuhan berat mutlak udang vaname Litopenaeus vanamei merupakan selisih berat rata-rata pada akhir pemeliharaan dengan awal pemeliharaan. Perhitungan pertumbuhan berat mutlak dapat dihitung dengan rumus (Effendi, 2003):

$W m=W t-W o$

Keterangan:

Wm : Perumbuhan berat mutlak (g)

Wt : Berat rata-rata akhir (g)

Wo : Berat rata-rata awal $(\mathrm{g})$

\section{Specific Growth Rate}

Specific growth rate (SGR) adalah presentase pertambahan udang setiap hari selama penelitian. Laju pertumbuhan harian udang dihitung dengan menggunakan rumus Far et al. (2009) sebagai berikut:

$\operatorname{SGR}(\%)=\frac{(\mathrm{LnWt}-\mathrm{LnWo})}{\mathrm{t}} \times 100 \%$

Keterangan:

SGR = Laju Pertumbuhan Harian \%

$\mathrm{Wt}=$ Berat tubuh rata-rata pada akhir pemeliharaan $(\mathrm{g})$

Wo = Berat tubuh rata-rata pada awal pemeliharaan $(\mathrm{g})$

$\mathrm{t} \quad=$ Lama waktu pemeliharaan.

\section{Survival Rate}

Survival rate (SR) atau tingkat kelangsungan hidup adalah perbandingan jumlah udang yang hidup sampai akhir pemeliharaan dengan jumlah udang pada awal pemeliharaan, yang dihitung menggunakan rumus:

$S R=\frac{N t}{N o} \times 100 \%$

Keterangan:

$\mathrm{SR}=$ Tingkat kelangsungan hidup (\%)

$\mathrm{Nt} \quad=$ Jumlah udang hidup pada akhir pemeliharaan (ekor)

No = Jumlah udang pada awal pemeliharaan (ekor).

\section{Biomassa}

Biomassa merupakan total bobot udang hidup selama akhir penelitian. Biomassa dalam penelitian ini berupa total bobot udang yang dipelihara selama 35 hari dalam satuan gram. Perhitungan biomassa udang dapat dilakukan dengan cara menimbang semua berat udang 
pada akhir penelitian menggunakan timbangan Kualitas air

digital.

\section{Feed Conversion Ratio}

Feed Conversion Ratio (FCR) merupakan jumlah pakan yang diberikan untuk menghasilkan biomasa udang. FCR dihitung menggunakan rumus Effendi (2003):

$F C R=\frac{F}{W t-W o} ;$

Keterangan:

FCR : Feed conversion ratio

$\mathrm{F} \quad$ : Jumlah pakan yang diberikan selama pemeliharaan $(\mathrm{g})$

Wt : Biomassa akhir $(\mathrm{g})$

Wo : Biomassa awal (g)

\section{Efisiensi Pakan}

Efisiensi pakan (EP) merupakan perbandingan biomassa udang dengan jumlah pakan yang diberikan selama masa pemeliharaan. Efisiensi pakan dapat dihitung dengan menggunakan rumus Takeuchi (1988):

$E P=\frac{(W t+W d)-W o}{F} \times 100 \%$

Keterangan:

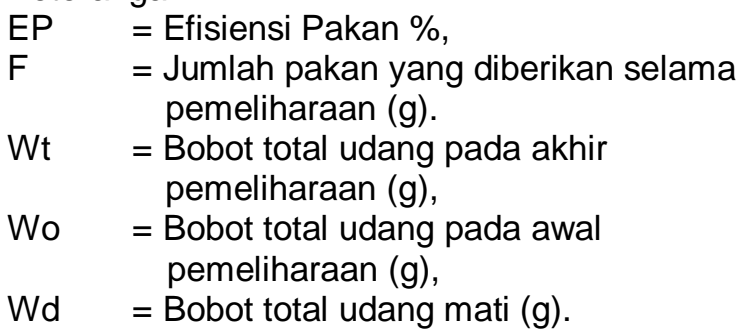

Pengukuran kualitas air dilakukan pada awal, tengah, dan akhir penelitian. Parameter kualitas air yang diamati meliputi amoniak $\left(\mathrm{NH}_{3}\right)$, nitrit $\left(\mathrm{NO}_{2}{ }^{-}\right)$, suhu, $\mathrm{pH}$, dissolved oxygen (DO), total suspended solid (TSS), volume floc, dan total bacteria count (TBC).

\section{Analisis Data}

Data hasil penelitain dianalisis dengan analisis sidik ragam (Anova) dengan tingkat kepercayaan 95\% menggunakan aplikasi SPSS 16.0. Untuk mengetahui perbedaan masing-masing perlakuan, digunakan uji beda nyata (BNT).

HASIL DAN PEMBAHASAN Hasil Uji Kandungan Karbon dan Nitrogen

Sumber karbon yang digunakan pada penelitian berupa gandum, tapioka, dan molase. Hasil uji sumber karbon organic dan nitrogen dapat dilihat pada Tabel 1.

Tabel 1. Hasil Uji Sumber Karbon dan nitrogen

\begin{tabular}{cccc} 
No & $\begin{array}{c}\text { Sumber } \\
\text { karbon } \\
\text { organic }\end{array}$ & $\begin{array}{c}\text { C- } \\
\text { organik } \\
(\%)\end{array}$ & $\begin{array}{c}\text { Nitrogen } \\
\text { (Amoniak) (\%) }\end{array}$ \\
\hline 1 & Gandum & 41,65 & 1,17 \\
2 & Tapioka & 53,25 & 0,584 \\
3 & Molase & 37,45 & 0,228 \\
\hline
\end{tabular}

\section{Pertumbuhan}

Pertumbuhan Berat Mutlak

Pertumbuhan berat mutlak udang vaname yang dipelihara pada sistem biofloc menggunakan sumber karbon yang berbeda berkisar antara 4,8 $\pm 0,1 \mathrm{~g}$ hingga $4,9 \pm 0,1 \mathrm{~g}$ (Gambar 1$)$.

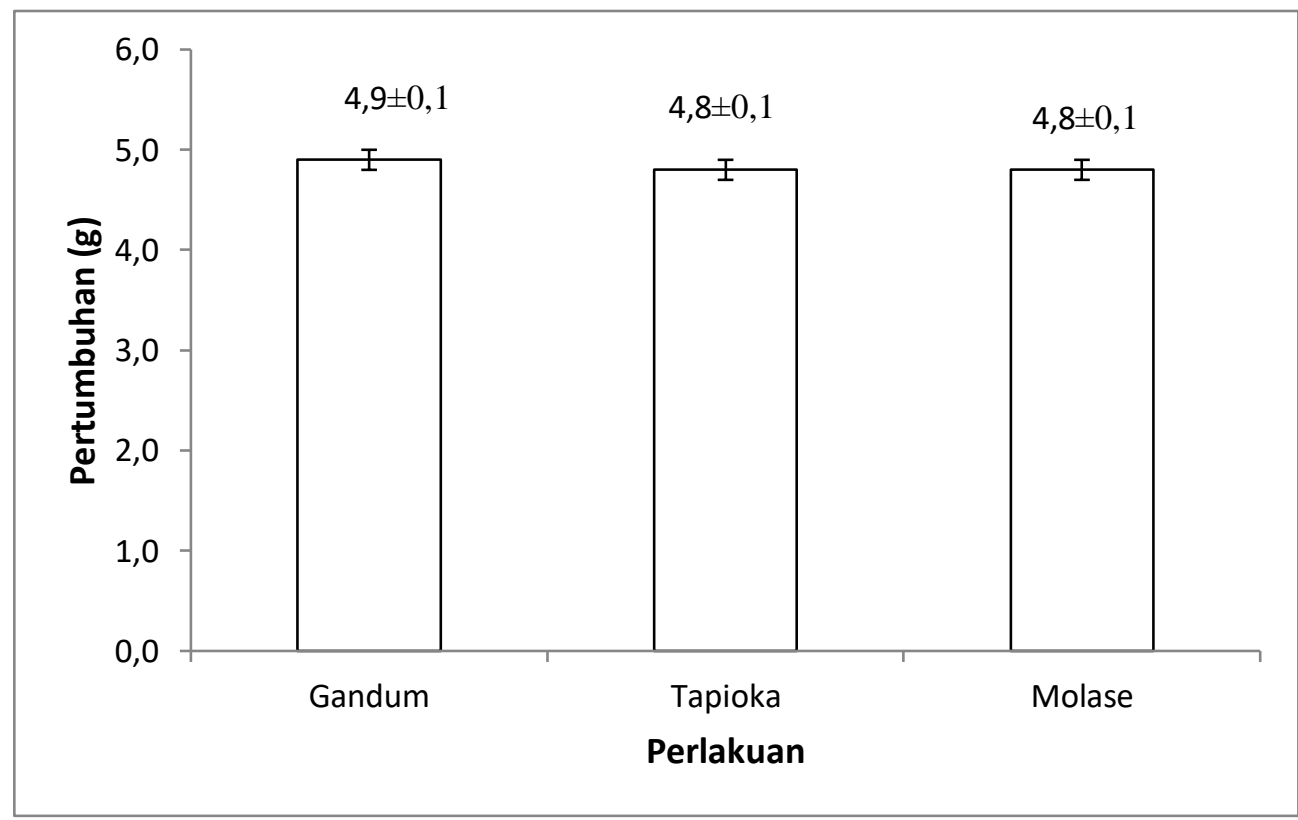

Gambar 1. Pertumbuhan berat mutlak $L$. vannamei pada sistem biofloc dengan sumber karbon berbeda 
Supono et al., Performa Udang Vaname Litopenaeus vannamei

Berdasarkan hasil uji statistik Anova pada tingkat kepercayaan 95\% menunjukkan bahwa penambahan sumber karbon yang berbeda pada sistem biofloc tidak berpengaruh nyata terhadap pertumbuhan berat mutlak udang vaname.

\section{Specific Growth Rate}

Specific growth rate (SGR) atau laju pertumbuhan spesifik merupakan persentase pertumbuhan bobot yang dihasilkan selama 35 hari pemeliharaan. Nilai SGR udang vaname yang dipelihara pada sistem biofloc dengan sumber karbon yang berbeda berkisar antara $13,98 \pm 0.03 \%$ hingga $14,02 \pm 0.06 \%$ (Gambar 2). Berdasarkan hasil uji statistik Anova pada tingkat kepercayaan 95\% menunjukkan bahwa penambahan sumber karbon yang berbeda pada sistem biofloc tidak berpengaruh nyata terhadap laju pertumbuhan spesifik udang vaname.

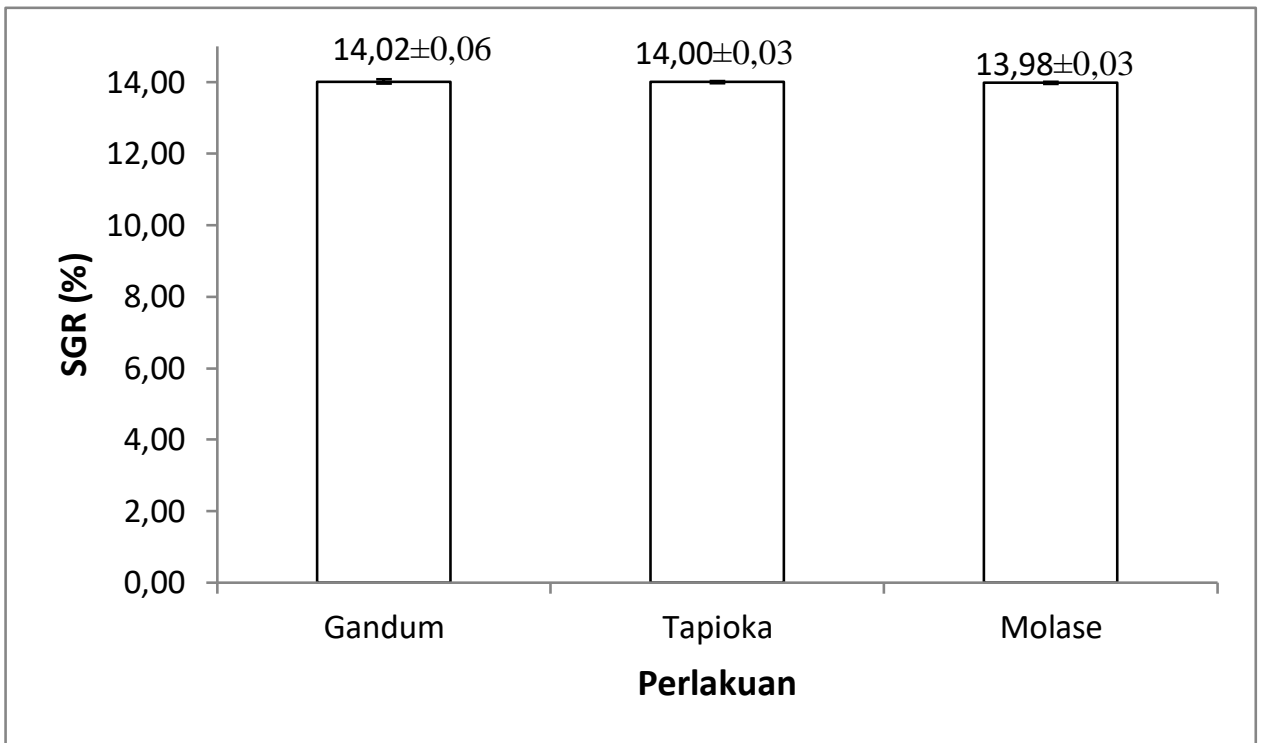

Gambar 2. Specific growth rate (SGR) L. vannamei pada sistem biofloc dengan sumber karbon berbeda

\section{Survival Rate}

Survival rate (SR) atau tingkat kelangsungan hidup merupakan perbandingan jumlah udang yang hidup sampai akhir pemeliharaan dengan jumlah udang pada awal pemeliharaan. Hasil penelitian menunjukkan nilai SR udang vaname menggunakan sistem biofloc bervariasi antara $58 \%$ (molase) sampai $75 \%$ (gandum) seperti yang terdapat pada Gambar 3.

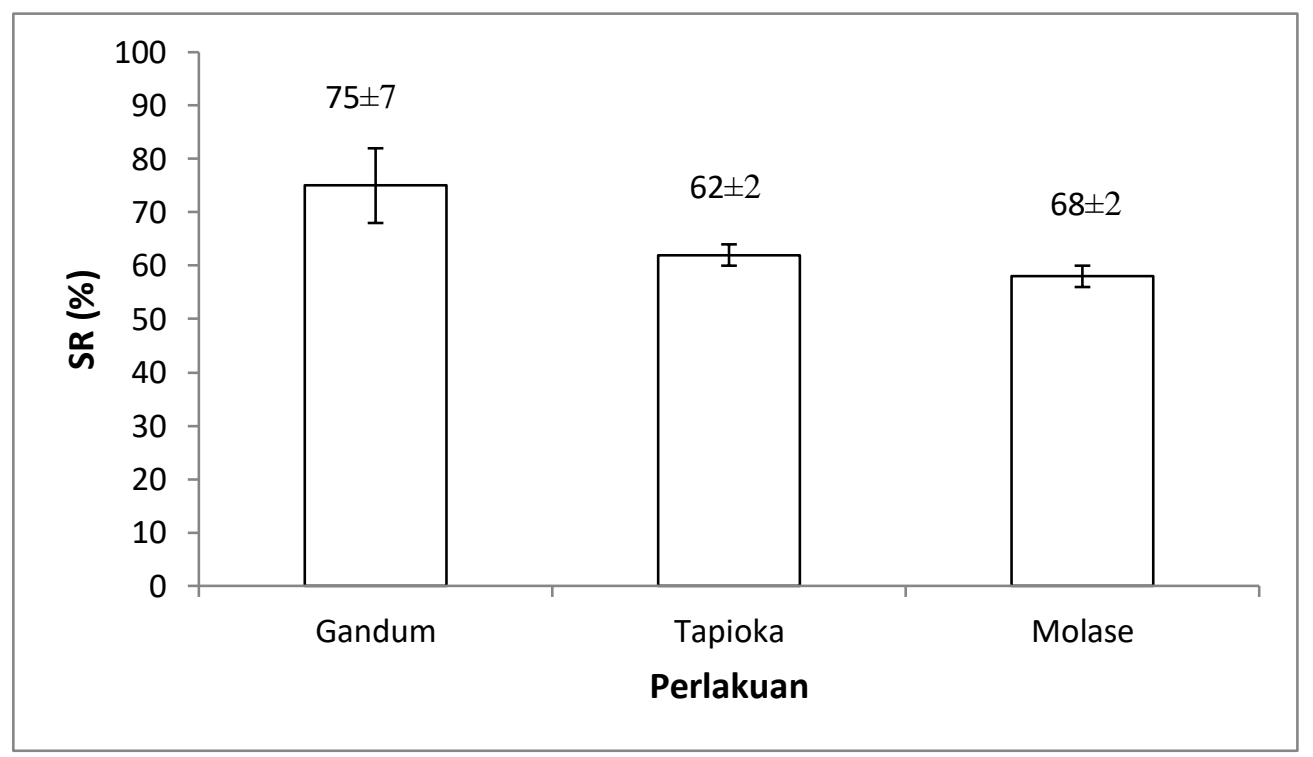

Keterangan = A: Gandum, B: Tapioka, C: Molase

Gambar 3. Survival rate L. vannamei pada sistem biofloc dengan sumber karbon berbeda 
Berdasarkan hasil uji statistik Anova pada selang kepercayaan 95\% menunjukkan bahwa penambahan sumber karbon berbeda pada sistem biofloc berpengaruh nyata terhadap nilai SR udang vaname. Berdasarkan uji BNT diketahui bahwa perlakuan penambahan sumber karbon gendum (A) berbeda nyata dengan perlakuan sumber karbon tapioka (B) dan molase (C).

\section{Biomassa}

Biomassa merupakan total bobot udang vaname hidup hingga akhir penelitian. Nilai biomassa udang vaname dengan sistem biofloc menggunakan sumber karbon organik gandum sebesar 256,8 $\pm 23,6 \mathrm{~g}$, tapioka sebesar 214,3 $\pm 6,9 \mathrm{~g}$ dan molase sebesar 202,4 $\pm 4,3 \mathrm{~g}$ (Gambar 4).

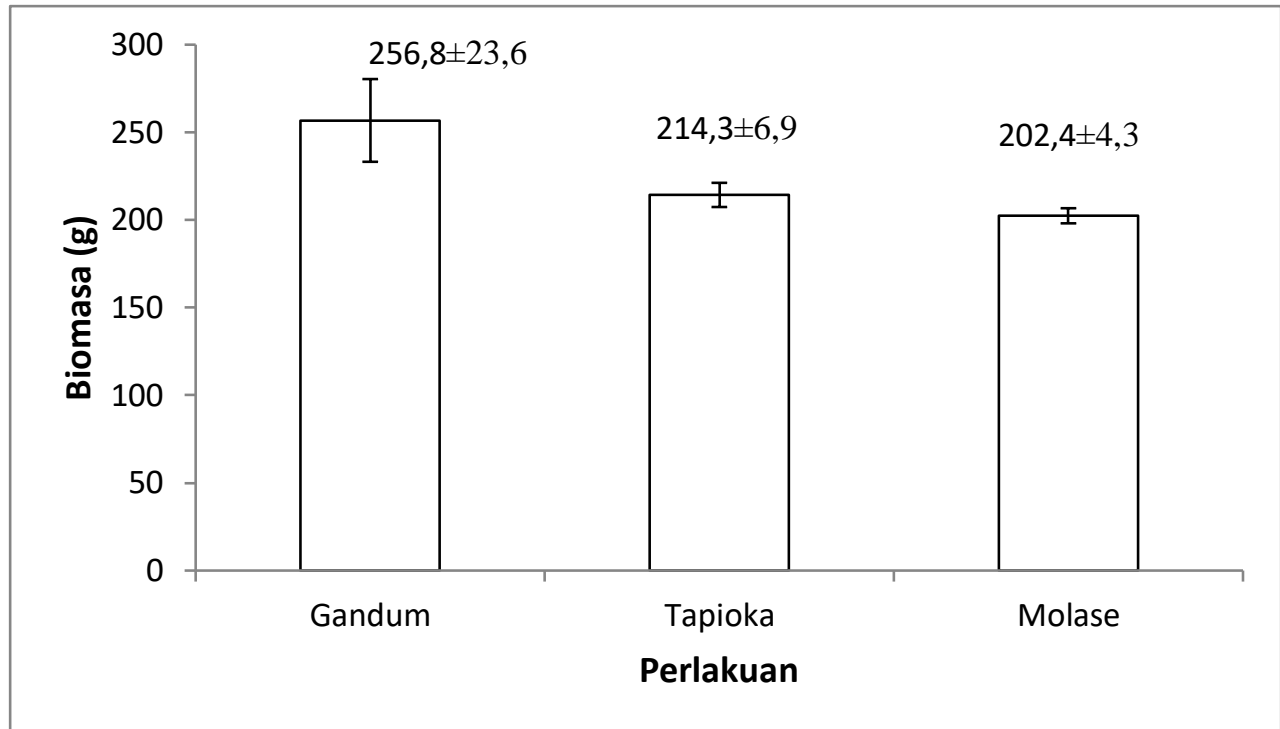

Gambar 4. Biomassa udang L. vannamei pada sistem biofloc dengan sumber karbon berbeda

Berdasarkan hasil uji statistik Anova pada selang kepercayaan $95 \%$ menunjukkan bahwa penambahan sumber karbon berbeda pada sistem biofloc berpengaruh nyata terhadap nilai biomassa udang vaname. Berdasarkan uji BNT diketahui bahwa biomasa udang $L$. vannamei pada perlakuan penambahan sumber karbon gandum pada sistem biofloc berbeda nyata dengan perlakuan sumber karbon tapioka dan molase.

\section{Feed conversion ratio}

Feed conversion ratio (FCR) udang L. vannamei bervariasi dari masing-masing perlakuan. Sumber karbon gandum menghasilkan FCR $1,3 \pm 0,1$, sumber karbon organik tapioka $1,6 \pm 0,1$ dan sumber karbon organik molase sebesar $1,8 \pm 0,1$ (Gambar 5).

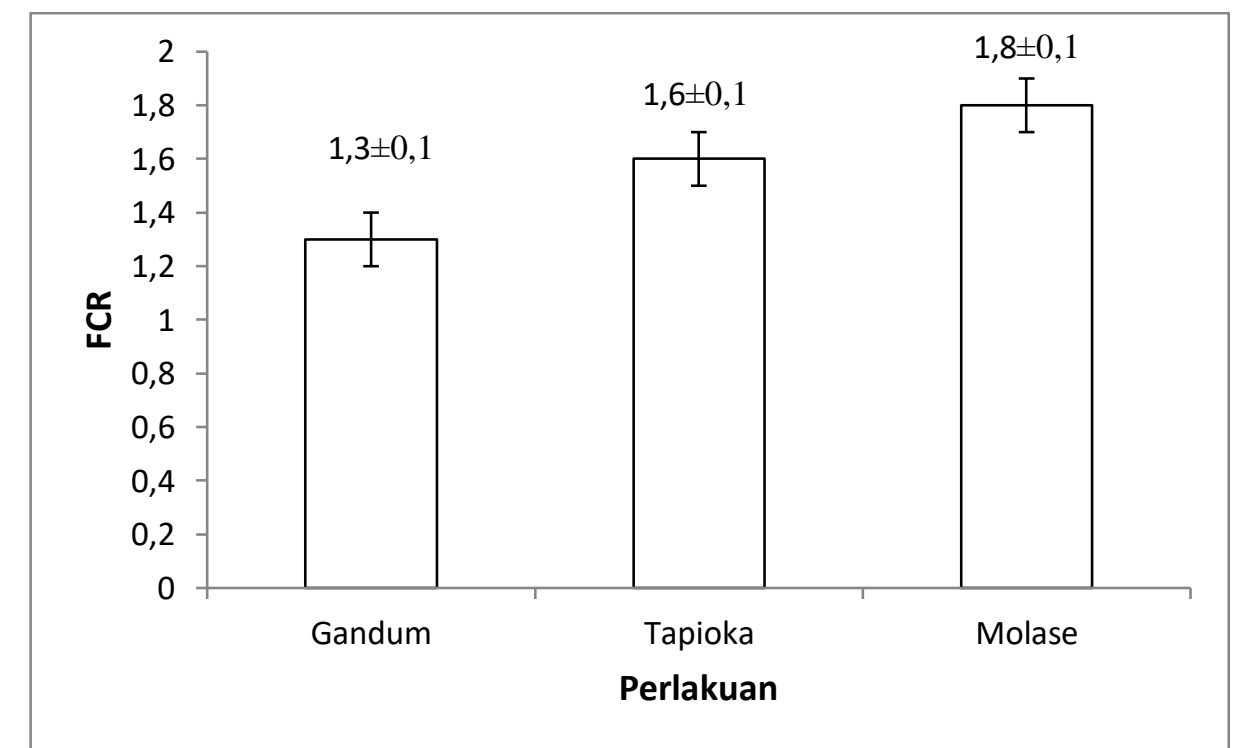

Gambar 5.Feed conversion ratio udang L. vannamei pada sistem biofloc dengan sumber karbon organik yang berbeda 
Berdasarkan hasil uji statistik Anova pada selang kepercayaan 95\% menunjukkan bahwa penambahan sumber karbon yang berbeda pada sistem biofloc berpengaruh nyata terhadap nilai FCR udang $L$. vannamei. Berdasarkan uji BNT diketahui bahwa perlakuan penambahan sumber karbon gandum berbeda nyata dengan perlakuan sumber karbon tapioka, dan molase.

\section{Efisiensi Pemanfaatan Pakan}

Hasil penelitian menghasilkan nilai efisiensi pemanfaatan pakan udang vaname menggunakan sistem biofloc yaitu perlakuan sumber karbon gandum sebesar $74,9 \pm 7.3 \%$, tapioka $60,8 \pm 2,2 \%$, dan molase sebesar $56,1 \pm 1.6 \%$ (Gambar 6).

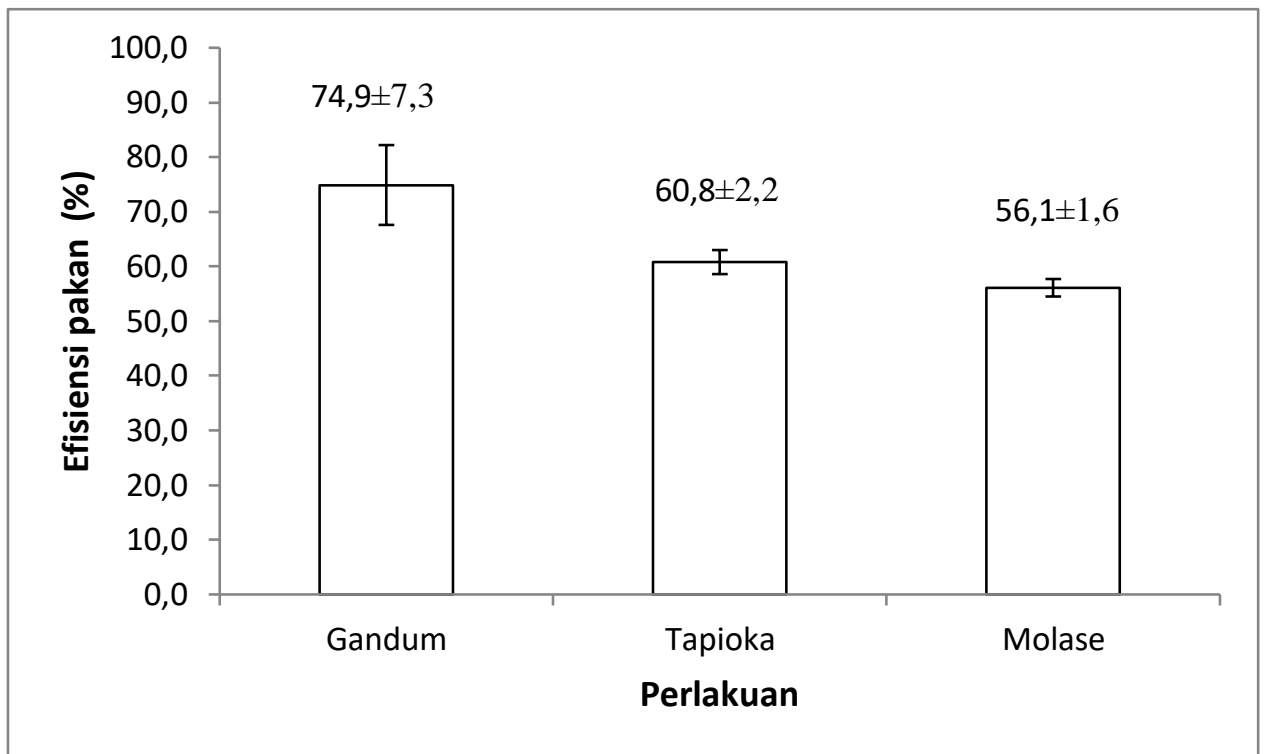

Gambar 6. Efisiensi pemanfaatan pakan L. vannamei pada sistem biofloc dengan sumber karbon berbeda

Berdasarkan hasil uji statistik Anova pada selang kepercayaan $95 \%$ menunjukkan bahwa penambahan sumber karbon berbeda pada sistem biofloc berpengaruh nyata terhadap nilai efisiensi pemanfaatan pakan udang vaname. Berdasarkan uji BNT diketahui nilai efisiensi pemanfaatan pakan pada perlakuan penambahan sumber karbon gandum berbeda nyata dengan perlakuan sumber karbon tapioka dan molase.

\section{Kualitas Air}

Kualitas air berperan penting dalam proses penentu pertumbuhan dan kelangsungan hidup udang vaname. Parameter kualitas air yang diukur selama penelitian yaitu amonia $\left(\mathrm{NH}_{3}\right)$, Nitrit $\left(\mathrm{NO}_{2}\right)$, Volume floc, Total Suspended Solid (TSS), oksigen terlarut (DO), Total Bacteria Count (TBC), suhu, dan $\mathrm{pH}$.. Hasil pengukuran kualitas air selama penelitian dapat dilihat pada Tabel 2.

Tabel 2. Hasil pengukuran kualitas air selama penelitian

\begin{tabular}{lccccc}
\hline PARAMETER & HARI KE & A (Gandum) & $\begin{array}{c}\text { PERLAKUAN } \\
\text { B (Tapioka) }\end{array}$ & C (Molase) & $\begin{array}{c}\text { Kisaran } \\
\text { optimum }\end{array}$ \\
\hline amoniak (mg/L) & 15 & 0,09 & 0,02 & 0,02 & $<0,1$ \\
nitrit (mg/L) & 32 & 0,01 & 0,01 & 0,01 & \\
& 15 & 0,3 & 0,3 & 0,3 & $<0,1$ \\
Vol. floc (ml/L) & 32 & $<0,3$ & $<0,3$ & 0,3 & \\
TSS (mg/L) & 15 & 1.5 & 1.5 & 2 & \\
& 30 & 6 & 3 & 10 & $150-200$ \\
DO (mg/L) & 10 & 166 & 170 & 172 & $>4$ \\
& 30 & 274 & 272 & 276 & \\
TBC (cfu/mL) & 3 & 4,6 & 4,6 & 4,6 & \\
& 20 & 5,7 & 5,7 & 5,7 & \\
Suhu $\left({ }^{\circ} \mathrm{C}\right)$ & 30 & 5,7 & 5,7 & 5,7 & \\
pH & 11 & $5,1 \times 10^{11}$ & $1,2 \times 10^{11}$ & $4,8 \times 10^{10}$ & \\
\hline
\end{tabular}

${ }^{*}$ SNI 8037.1:2014 


\section{Pembahasan}

Pertumbuhan

Nutrisi pakan merupakan salah satu faktor yang mempengaruhi pertumbuhan udang vaname. Pakan yang digunakan selama kegiatan penelitian berupa pakan komersil dengan kandungan protein $32 \%$. Selain pakan komersil, pemeliharaan menggunakan sistem biofloc diharapkan mampu menjadi sumber nutrisi untuk pertumbuhan udang vaname.Kandungan nutrisi pada sistem biofloc dipengaruhi oleh penambahan sumber karbon eksternal. Gandum, tapioka, dan molase merupakan sumber karbon eksternal yang digunakan selama pemeliharaan udang vaname. Sumber karbon yang digunakan dalam teknologi biofloc dapat berupa karbohidrat sederhana (monosakarida) dan karbohidrat kompleks (disakarida dan polisakarida) (Avnimelech, 2015).

Sumber karbon tapioka dan gandum merupakan sumber karbon kompleks yang sulit dimetabolisme oleh bakteri, namun sumber karbon kompleks mampu menyediakan partikelpartikel yang dapat dimanfaatkan oleh bakteri sebagai tempat menempel (Chamberlain et al., 2001). Sementara molase merupakan sumber karbon organik yang mudah larut dan mudah diserap oleh bakteri sehingga amoniak yang ada di air lebih cepat terikat. Suryani et al., (2011) menyatakan bahwa karbohidrat yang sederhana akan lebih cepat diasimilasi oleh bakteri namum dapat menyebabkan floc yang ada di perairan tersebut mudah mati. Sehingga dengan penambahan sumber karbon berupa gandum, tapioka, dan molase dalam sistem biofloc mampu memicu pertumbuhan dan perkembangan bakteri heterotrof selanjutnya bakteri heterotrof di dalam media pemeliharaan akan dimanfaatkan sebagai sumber nutrisi untuk pertumbuhan udang vaname.

Berdasarkan hasil penelitian, penggunaan sumber karbon berbeda pada sistem biofloc tidak berpengaruh nyata terhadap pertumbuhan berat mutlak dan SGR udang vaname. Hasil ini sama dengan hasil penelitian Aji et al., (2014) yang menjelaskan bahwa penambahan sumber karbon berupa molase dan gandum tidak memberikan pengaruh terhadap laju pertumbuhan harian pada ikan lele (Clarias sp.) yang dipelihara dalam media biofloc. Gunarto et al., (2010) juga menjelaskan bahwa penambahan sumber karbon berupa tepung tapioka dan fermentasi probiotik pada pemeliharaan udang windu selama 112 hari tidak memberikan pengaruh nyata terhadap pertumbuhan udang windu.

\section{Survival Rate (SR)}

Nilai SR tertinggi yaitu pada perlakuan B (gandum) dengan nilai $75,4 \pm 7.2 \%$. Tingginya derajat kelangsungan hidup pada perlakuan penambahan sumber karbon gandum disebabkan dalam media pemeliharaan terdapat pakan yang selalu tersedia dalam bentuk floc, sehingga udang tidak merasa kekurangan makan serta mampu meminimalkan sifat kanibal antar individu. Penambahan sumber karbon berbeda memengaruhi keberadaan total bakteri di media pemeliharaan (Tabel 4). Berdasarkan hasil penelitian nilai total bakteri pada penambahan sumber karbon molase mengalami peningkatan yang signifikan pada pengukuran pertama dan kedua dibandingkan dengan sumber karbon gandum dan tapioka. Nilai total bakteri dengan penambahan sumber karbon molase pada pengukuran pertama (hari ke 11) yaitu $4,8 \times 10^{10} \mathrm{cfu} / \mathrm{mL}$ dan terjadi peningkatan sebesar $8,1 \times 10^{12} \mathrm{cfu} / \mathrm{mL}$ pada pengukuran kedua (hari ke 27). Meningkatnya nilai total bakteri Bacillus coagulans di air pada perlakuan molase diduga karena sumber karbon molase merupakan sumber karbon sederhana (monosakarida) sehingga $B$. coagulans lebih mudah dalam memanfaatkan sumber karbon tersebut sebagai energi dalam menyusun biofloc (Avnimelech, 2015).

Perbedaan sumber karbon tidak mengakibatkan kematian udang vaname secara signifikan. Hal ini dapat terjadi karena keberadaan mikrobial floc yang ditandai dengan tingginya nilai TSS (total suspended solid) dapat diterima dengan baik dan tidak berpengaruh nyata terhadap tingkat kelangsungan hidup udang vaname. Hasil pengamatan kadar TSS pada media pemeliharan udang vaname pada awal pemeliharaan yakni $166 \mathrm{mg} / \mathrm{L}$ pada perlakuan gandum, tapioka 170 $\mathrm{mg} / \mathrm{L}$, dan molase sebesar $172 \mathrm{mg} / \mathrm{L}$. Hingga akhir pemeliharaan kandungan TSS yang diperoleh pada perlakuan perlakuan sumber karbon organic gandum sebesar $274 \mathrm{mg} / \mathrm{L}$, tapioka $272 \mathrm{mg} / \mathrm{L}$, dan molase $276 \mathrm{mg} / \mathrm{L}$. Peningkatan kandungan TSS ini disebabkan karena adanya konversi limbah $\mathrm{N}$ dari kegiatan budidaya udang vaname dengan penambahan C-organik dari gandum, molase dan tapioka menjadi mikroorganisme heterotrof yang selanjutnya membentuk floculasi (Avnimelech, 2015).

Total suspended solid tidak bersifat toksik bagi organisme air, tetapi tingginya nilai tersebut dapat menghambat penetrasi cahaya ke dalam air (Effendi, 2003). Nilai TSS pada media air pemeliharaan udang vaname berkisar antara 50 sampai $300 \mathrm{mg} / \mathrm{L}$ sesuai dengan teknologi akuakultur berbasis biofloc dimana TSS yang 
dianjurkan berkisar 200 sampai $1000 \mathrm{mg} / \mathrm{L}$ (De Schryver et al., 2008). Volume floc dari semua perlakuan menunjukkan nilai yang cenderung meningkat pada akhir masa pemeliharaan baik dengan penambahan sumber karbon maupun pada kontrol. Peningkatan volume floc tertinggi yaitu pada penambahan sumber karbon molase sebesar $2 \mathrm{ml} / \mathrm{L}$ menjadi $10 \mathrm{ml} / \mathrm{L}$, selanjutnya diikuti oleh penambahan sumber karbon gandum yaitu $1,5 \mathrm{ml} / \mathrm{L}$ menjadi $6 \mathrm{ml} / \mathrm{L}$, dan tapioka 1,5 $\mathrm{ml} / \mathrm{L}$ menjadi $3 \mathrm{ml} / \mathrm{L}$. Volume floc merupakan salah satu indikator terjadinya floculasi pada media pemeliharaan. Floc yang terbentuk tersebut mampu dimanfaatkan udang sebagai pakan alami bagi udang vaname (Almuqaramah et al., 2018).

Kualitas air mempunyai peranan penting sebagai pendukung kehidupan dan pertumbuhan udang vaname. Rendahnya kualitas air pada media pemeliharaan dapat mengakibatkan rendahnya tingkat pertumbuhan, sintasan, dan peningkatan bakteri yang merugikan. Kualitas air media pemeliharaan selama penelitian masih berada pada kisaran yang layak bagi sintasan udang. Nilai amonia pada penelitian ini berkisar antara $0,09 \mathrm{mg} / \mathrm{L}-0,01 \mathrm{mg} / \mathrm{L}$. Konsentrasi $\mathrm{NH} 3$ yang relatif aman untuk udang Penaeus sp. adalah di bawah $0,1 \mathrm{mg} / \mathrm{L}$ (Liu, 1989). Nilai nitrit hingga akhir pemeliharaan mengalami penurunan hingga $<0,3 \mathrm{mg} / \mathrm{L}$ pada perlakuan sumber karbon dan $0,8 \mathrm{mg} / \mathrm{L}$ pada perlakuan kontrol (tanpa biofloc). Kandungan nitrit yang dapat diltoleransi oleh udang vaname berkisar $0,1-1$ $\mathrm{mg} / \mathrm{L}$. Hasil pengamatan oksigen terlarut pada penelitian ini berkisar 4,6-5,7 mg/L. Kadar oksigen ini sangat mendukung untuk terbentuknya biofloc pada media pemeliharaan dan berperan dalam penyedia oksigen bagi udang. Nilai suhu pada penelitian berkisar antara $26-28^{\circ} \mathrm{C}$ dan nilai $\mathrm{pH}$ yaitu berkisar antara $7,3-$ 7,8 pada masing-masing perlakuan.

\section{Biomassa}

Berdasarkan hasil penelitian diperoleh bahwa penambahan sumber karbon organik gandum menghasilkan nilai biomassa yang berbeda nyata dengan penambahan sumber karbon organik tapioka dan molase. Nilai biomassa tertinggi pada pemeliharaan udang vaname yaitu pada penambahan sumber karbon berupa gandum, menghasilkan nilai biomassa sebesar $256,8 \pm 23,6 \mathrm{~g}$ dan nilai biomassa terendah yaitu pada penambahan sumber karbon molase sebesar 202,4 $\pm 4,3 \mathrm{~g}$ selama 35 hari pemeliharaan. Avnimelech et al., (2009) menyatakan bahwa penggunaan jenis sumber karbon yang berbeda akan memberikan hasil yang berbeda dimana komposisi floc bisa sangat berbeda tergantung pada substrat karbon yang digunakan untuk menumbuhkan floc.

Sumber karbon yang digunakan pada pemeliharaan udang vaname berupa sumber karbon komplek (polisakarida) dan sederhana (monosakarida). Polisakarida yang digunakan berupa tepung gandum dan tapioka. Menurut Suryani et al., (2011), tepung terigu atau gandum termasuk dalam karbohidrat yang komplek, yang mempunyai keunggulan yaitu dapat menyediakan partikel-partikel yang dapat dijadikan tempat menempelnya bakteri. Partikel tersebut juga akan memudahkan proses pelepasan karbon organik dan tahan lama sebagai substrat bakteri. Penambahan sumber karbon molase pada pemeliharaan udang vaname menghasilkan nilai TBC dan volume floc tertinggi dibandingkan dengan penambahan sumber karbon gandum dan tapioka. Floc yang terbentuk akan dimanfaatkan udang sebagai subtitusi pakan tambahan untuk peningkatan biomassanya. Namun berdasarkan hasil penelitian, nilai biomassa udang vaname dengan penambahan sumber karbon molase menunjukkan nilai yang lebih rendah dibandingkan dengan penambahan sumber karbon gandum dan tapioka.

Menurut Suryani et al., (2011), karbohidrat sederhana (molase) akan lebih cepat di asimilasi oleh bakteri namum dapat menyababkan floc yang ada di perairan tersebut mudah mati. Dengan demikian tingginya nilai TPC dan volume floc yang terbentuk pada perlakuan sumber karbon molase tidak mampu dimanfaatkan udang vaname secara optimum sebagai subtitusi pakan tambahan untuk peningkatan biomassa.

\section{Konversi Pakan}

Kajian produktifitas udang vaname dapat terlihat dari nilai konversi pakan yang diperoleh selama pemeliharaan. Nilai feed conversion ratio (FCR) menggambarkan efektifitas pakan yang dikonsumsi oleh udang. Penggunaan sumber karbon berbeda pada sistem biofloc berpengaruh nyata terhadap nilai FCR dan efisiensi pemanfaatan pakan udang vaname. Perlakuan sumber karbon organik gandum menghasilkan nilai FCR terendah yaitu $1,3 \pm 0,1$ dan nilai $F C R$ tertinggi terdapat pada perlakuan sumber karbon organic molase dengan nilai $1,8 \pm 0,1$. Semakin kecil nilai FCR berarti pakan semakin berkualitas, hal ini menunjukkan bahwa jumlah pakan yang dikonsumsi lebih besar dari pada jumlah pakan yang tersisa.

Biomassa bakteri heterotrof dapat membentuk agregat (floc) bersama dengan mikroba lain, yang selanjutnya dapat dimanfaatkan oleh 
Jurnal Kelautan, 14(2), 192-202 (2021)

organisme budidaya (De Schryver et al.,2008). Pada beberapa spesies lain yang dibudidayakan memberikan hasil dimana biofloc dapat digunakan sebagai sumber pakan alami yang memiliki kandungan protein $37-38 \%$ (Azim dan Little, 2008). Hasil ini sesuai dengan hasil penelitian Apriani et al., (2016) yang menyatakan bahwa pemberian sumber karbon berbeda pada media biofloc mampu menekan nilai konversi pakan benih ikan patin.

Nilai efisensi pemanfaatan pakan tertinggi ditemukan pada perlakuan penambahan sumber karbon organik gandum sebesar $74,9 \pm 7,3 \%$, diikuti dengan sumber karbon organik tapioka yaitu $60,8 \pm 2,1 \%$, dan nilai efisiensi pemanfaatan pakan terendah terdapat pada perlakuan sumber karbon organik molase dengan nilai $56,1 \pm 1,6 \%$. Widanarni et al., (2010) menyatakan bahwa efisiensi pakan pada perlakuan dengan aplikasi teknologi biofloc sedikit lebih tinggi karena adanya peningkatan biomassa biofloc sebagai sumber nutrisi atau makanan tambahan bagi kultivan budidaya.

\section{KESIMPULAN DAN SARAN}

Teknologi biofloc dengan sumber karbon gandum berpengaruh nyata dengan sumber karbon tapioka dan molase terhadap tingkat kelangsungan hidup, biomassa, dan konversi pakan udang vaname. Sumber karbon gandum menghasilkan performa produktivitas terbaik yaitu feed conversion ratio $(1,3 \pm 0,1)$, efisiensi pemanfaatan pakan $(74,9 \pm 7,3 \%)$, survival rate $(75,4 \pm 7,2 \%)$, dan biomassa $(256,8 \pm 23,6 \mathrm{~g})$. Pemberian sumber karbon berbeda tidak berpengaruh nyata terhadap pertumbuhan berat mutlak dan pertumbuhan spesifik udang vaname

\section{DAFTAR PUSTAKA}

Aji, S.B., Sudaryono A., dan Dicky H. (2014).Pengaruh Penambahan Sumber Karbon Organik Berbeda Terhadap Pertumbuhan Dan Rasio Konversi Pakan Benih Lele "(Clarias sp.)" Dalam Media Biofloc. Journal of Aquaculture Management and Technology, 3(4), 199206.

Almuqaramah, T.M.H., Setiawati M., Priyoutomo N.B., dan Effendi I. (2018). Pendederan Udang Vaname Litopenaeus Vannamei Dengan Teknologi Biofloc Untuk Meningkatkan Pertumbuhan dan Efisiensi Pakan.Jurnal IImu dan Teknologi Kelautan Tropis, 10(1), 143152.

Apriani, I., Setiawati, M., \& Budiardi, T. (2016). Produksi yuwana ikan patin Pangasianodon hypophthtalmus
(Sauvage 1878) pada sistem budi daya berbasis bioflok dengan penambahan sumber karbon berbeda. Jurnal Iktiologi Indonesia, 16(1), 75-90.

Avnimelech, Y. (2009). Biofloc Technology: A Practical Guide Book. World Aquaculture Society: Louisiana, USA. 120p.

Avnimelech, Y. (2015). Biofloc Technology- A Practical Guide Book, third edition. United States, The World Aquaculture Society. 259 p.

Azim, M. E., \& Little, D. C. (2008). The biofloc technology (BFT) in indoor tanks: water quality, biofloc composition, and growth and welfare of Nile tilapia (Oreochromis niloticus). Aquaculture, 283(1-4), 29-35.

Boon, N., Defoirdt T., de Windt W., Van De Wiele T., dan Verstraete W. (2010). Hydroxybutyrate and PolyHydroxybutyrate as Components of Animal Feed or Feed Additives. Patent Application Publication. April: 1-4.

Bossier, P. (2010). Poly- $\beta$-hydroxybutyrate (PHB) Increases Growth Performance and Intestinal Bacterial Range-Weighted Richness in Juvenile European Sea Bass. Applied Microbiology and Biotechnology 86 (5): 1535-1541.

Chamberlain, G., Avnimelech, Y., Mclntosh, R. P., \& Velasco, M. (2001). Advantages of aerated microbial reuse systems with balanced C: $\mathrm{N}-\mathrm{I}$ : Nutrient transformation and water quality benefits. Global aquaculture advocate, 4(2), 53-56.

Crab, R., Avnimelech, Y., Defoirdt, T., Bossier, P., \& Verstraete, W. (2007). Nitrogen removal techniques in aquaculture for a sustainable production. Aquaculture, 270(1-4), 1-14.

Crab, R., Lambert, A., Defoirdt, T., Bossier, P., \& Verstraete, W. (2010). The application of bioflocs technology to protect brine shrimp (Artemia franciscana) from pathogenic Vibrio harveyi. Journal of applied microbiology, 109(5), 1643-1649.

Crab, R., Defoirdt, T., Bossier, P., \& Verstraete, W. (2012). Biofloc technology in aquaculture: beneficial effects and future challenges. Aquaculture, 356, 351-356.

De Schryver P., Crab, R., Defoirdt, T., Boon, N., dan Verstraete, W. (2008). The Basics of Bioflocs Technology: The Added Value for Aquaculture Aquaculture, 277(3-4), 125-137.

De Schryver, P.D., A. K. Sinha, P. S. Kunwar, S K. Baruah, W. Verstraete, N. Boon, and G. De Boeck. 2010. Hydroxybutyrate (PHB) Increases Growth Performance and Intestinal Bacterial Range-Weighted Richness in Juvenile European Sea 
Bass, Dicentrarchus labrax. Applied Microbiology and Biotechnology, 86(5), 1535-1541

Ebeling, J. M., Timmons, M. B., \& Bisogni, J. J. (2006). Engineering analysis of the stoichiometry of photoautotrophic, autotrophic, and heterotrophic removal of ammonia-nitrogen in aquaculture systems. Aquaculture, 257(1-4), 346358.

Effendie, H. (2003). Telaah Kualitas Air: bagi Pengelolaan Sumber Daya dan Lingkungan Perairan. Gramedia. Jakarta.258hal.

Far, H. Z., Saad, C. R. B., Daud, H. M., Harmin, S. A., \& Shakibazadeh, S. (2009). Effect of Bacillus subtilis on the growth and survival rate of shrimp (Litopenaeus vannamei). African Journal of Biotechnology, 8(14), 3369-3376.

Gunarto, G., Muliani, M., \& Mansyur, A. (2016). Pengaruh Aplikasi Sumber CKarbohidrat (Tepung Tapioka) Dan Fermentasi Probiotik Pada Budidaya Udang Windu, Penaeus monodon Pola Intensif Di Tambak. Jurnal Riset Akuakultur, 5(3), 393-409.

Hargreaves, J. A. (2013). Biofloc production systems for aquaculture (Vol. 4503, pp. 1-11). Stoneville, MS: Southern Regional Aquaculture Center.

Haslun, J., Correia E., Strychar, K., Morris, T., and Samocha, T. (2012). Characterization of bioflocs in a no water exchange super-intensive system for the production of food size pacific white shrimp Litopenaeus vannamei. International Journal of Aquaculture, 2(6), 29-38.

Hien, N.T.T. (2012). Research and Application of Bioflocs Technology for Intensive Culture White Leg Shrimp Litopenaeus vannamei. Research Institute for Aquaculture, 1(5), 14-16.

Chen, J. C., Liu, P. C., \& Lin, Y. T. (1989). Culture of Penaeus monodon in an intensified system in Taiwan. Aquaculture, 77(4), 319-328.

Ogello, E.O., Musa, S.M., Christopher Mulanda Aura C.M., Abwao J.O., dan Munguti J.M. (2014). An Appraisal of the Feasibility of Tilapia Production in Ponds Using BioflocTechnology: A Review. International Journal of Aquatic Science, 5(1), 21-39

Piedrahita, R. H. (2003). Reducing the potential environmental impact of tank aquaculture effluents through intensification and recirculation. Aquaculture, 226(1-4), 3544.
Reddy, K. R., Feijtel, T. C., \& Patrick, W. H. (1986). Effect of soil redox conditions on microbial oxidation of organic matter. In The role of organic matter in modern agriculture (pp. 117-156). Springer, Dordrecht.

Sahu B.C., Adhikari S., dan Dey L. (2012). Carbon, nitrogen and phosphorus budget in shrimp (Penaeus monodon) culture ponds in eastern India. Aquaculture International, 2(1), 3-16.

Suguna, P., Binuramesh, C., Abirami, P., Saranya, V., Poornima, K., Rajeswari, V., \& Shenbagarathai, R. (2014). Immunostimulation by poly- $\beta$ hydroxybutyrate-hydroxyvalerate (PHB$\mathrm{HV}$ ) from Bacillus thuringiensis in Oreochromis mossambicus. Fish \& shellfish immunology, 36(1), 90-97.

Supono, S., Hutabarat, J., \& Prayitno, S. B. (2013). The effect of different $\mathrm{C}: \mathrm{N}$ and $\mathrm{C}$ : $\mathrm{P}$ ratio of media on the content of polyhydroxybutyrate in biofloc inoculated with bacterium Bacillus cereus. Journal of coastal development, 16(2), 114-120.

Supono, Hutabarat, J., Prayitno, S. B., Darmanto Y.S. (2014). White Shrimp (Litopenaeus vannamel) Culture using Heterotrophic Aquaculture System on Nursery Phase. International Journal of Waste Resources, 4(2), 1-4.

Supono. (2017). Teknologi Produksi Udang. Plantaxia, Yogyakarta, 168 hal

Ambarsari, L., Artika, I. M., \& Susanti, H. E. (2011). Characterization of bioflocculant producing-bacteria isolated from tapioca waste water. HAYATI Journal of Biosciences, 18(4), 193-196.

Takeuchi, T. (1988). Laboratory work chemical evaluation of dietarynutrient In Watanabe $T$, editor. Fish Nutrition and Marinculture. Tokyo. JICA Kanagawa International Fisheries Training Centre.179-225 p.

Yuniasari, D., \& Ekasari, J. (2010). Nursery culture performance of Litopenaeus vannamei with probiotics addition and different $\mathrm{C} / \mathrm{N}$ Ratio under laboratory condition. Hayati Journal of biosciences, 17(3), 115-119. 